\title{
Constitutional Structure and Statutory Formalism
}

\author{
John F. Manning $\dagger$
}

\section{INTRODUCTION}

Cass Sunstein puts formalists to their proof. In a thoughtful article, he maintains that judicial and academic debate about statutory formalism (and its operational arm, textualism) should shift from discussion of first principles to an investigation of the way formalism and antiformalism work in practice. ${ }^{1}$ His measured call for the facts shows how far formalism has come. Formalist judges no longer proclaim, as Justice Day once did, that "the duty of interpretation does not arise" when a statute has a plain meaning. ${ }^{2}$ And putting aside occasional moments of bravado, modern formalists do not rely much on the-law-is-the-law styles of argument. ${ }^{3}$ Modern formalists invoke political science, the philosophy of language, economics, and more. ${ }^{4}$ They talk

$\dagger$ Professor of Law, Columbia University. I am grateful to Vince Blasi, Michael Dorf, Beth Garrett, Debra Livingston, Henry Monaghan, Gerry Neuman, Peter Strauss, and Jeremy Waldron for valuable comments on an earlier draft. I thank Kevin Martin for excellent research assistance.

' See generally Cass R. Sunstein, Must Formalism Be Defended Empirically?, 66 U Chi L Rev 636 (1999).

2 Caminetti v United States, 242 US 470, 485 (1922).

3 Sunstein argues that such a style characterizes Justice Scalia's observation: "[O]f course it's formalist! The rule of law is about form."' See Sunstein, $66 \mathrm{U}$ Chi L Rev at 650 51 (cited in note 1), quoting Antonin Scalia, A Matter of Interpretation: The Federal Courts and the Law 25 (Princeton 1997). Nonetheless, Professor Sunstein also takes pains to note that Justice Scalia "is obviously aware" that any defense of formalism must refer to "something outside itself." Sunstein, $66 \mathrm{U}$ Chi L Rev at 651.

4 See, for example, Bank One Chicago, N.A. v Midwest Bank \& Trust Co, 516 US 264, 279-80 (1996) (Scalia concurring in part and concurring in the judgment) ("Many congressional committees tend not to be representative of the full House, but are disproportionately populated by Members whose constituents have a particular stake in the subject matter-agriculture, merchant marine and fisheries, science and technology, etc."); Continental Can Co v Chicago Truck Drivers, Helpers \& Warehouse Workers Union (Independent) Pension Fund, 916 F2d 1154, 1157 (7th Cir 1990) (opinion by Easterbrook) ("You don't have to be Ludwig Wittgenstein or Hans-Georg Gadamer to know that successful communication depends on meanings shared by interpretive communities."); Frank H. Easterbrook, The Supreme Court, 1983 Term: Foreword: The Court and the Economic System, 98 Harv L Rev 4, 15 (1984) ("If . . statutes often are designed to replace the outcomes of private transactions with monopolistic ones, to transfer the profits ('rents') of productive activity to a privileged few, then judges should take the beady-eyed contractual approach. The warehouseman does not deliver the grain without seeing the receipt, and so too with goodies dispensed by judges."). 
about incentives and make predictions about political, judicial, and private behavior. Facts are surely welcome.

Yet, it is perhaps premature to pronounce that the only, or even the most important, remaining assessment of formalism is factual. In the absence of any meaningful consensus about the relevant background values ${ }^{5}$ - the law to be applied to the facts, as it were-there surely remains room for conceptual, as well as empirical, inquiry and debate. Sunstein, for example, argues that we should compare how well formalism and antiformalism function as market-mimicking default rules, roughly defined as rules that replicate what Congress would have done had it explicitly spoken to a particular interpretive question. ${ }^{6}$ Leaving aside the difficult question of how to construct a meaningful empirical test of that counterfactual proposition (formalists argue that it is impossible), one must first ask why that or any other conceivable interpretive value-equity, transparency, coherence, deliberation, lower decision costs, higher decision costs, etc.-should qualify as a proper benchmark for empirical testing.

This Comment argues that in a limited constitutional democracy, any such inquiry must begin with the constitutional structure. That is to say, before testing whether a default rule promotes any particular interpretive value, we must first ascertain whether the Constitution either enjoins or permits the judiciary to recognize such a value as worthy of promotion. ${ }^{7}$ Building on this premise (defended below), I take issue with Sunstein's contention that the Constitution has little to say about the choice between formalist and antiformalist methodologies, and that the balance of the interpretive debate should focus on which "approach leads to the most sensible system of interpretation." It is true that even state-of-the-art formalists, at times, invite justifiable skepticism by making overstylized constitutional arguments about the implications of bicameralism and presentment, the requirements of democracy, and the like. Still, I suggest that structural constitutional analysis must, or at least should, provide the starting point for evaluating the basic interpretive commitments of formalism and antiformalism. The modern formalist's (and, for that matter, antiformalist's) occasional overstatement of the case does not warrant rejection of constitutional analysis in the interpretive debate; if anything, it calls for a more textured inquiry

see Section III.

- See Sunstein, 66 U Chi I Rev at 651, 653-55 (cited in note 1).

7 For purposes of convenience, I will focus on judicial interpretation of statutes. Similar principles, however, would apply to the executive's interpretation of statutes.

- See id at 662-63. 
into what the Constitution does and does not tell us about the values that courts and agencies should bring to the interpretation of statutory commands. Such analysis ultimately should cast light on the valuable question that Sunstein has raised-whether and to what extent empirical analysis might help to assess the competing claims of formalism and antiformalism. This Comment considers these issues in turn. These remarks are meant to be tentative-raising matters for further inquiry rather than attempting to provide definitive answers.

\section{THE NATURE OF SUNSTEIN's SkEPTICISM}

Professor Sunstein's skepticism about the constitutional defense of formalism does not reflect an outright rejection of constitutionalism in matters of statutory interpretation. In the past, he has made forceful and important arguments that courts should design interpretive norms to promote the civic republican values that he discerns in the constitutional design. ${ }^{9} \mathrm{He}$ also has contended that constitutionally inspired norms should sit atop the hierarchy of interpretive principles that guide courts and administrators in making sense of federal statutes. ${ }^{10}$ These observations are consistent with the tenor of Professor Sunstein's present remarks about constitutionalism, which appear to rest mainly on the contention that moderm formalists have not persuasively made their constitutional case. ${ }^{11}$

Modern formalists bear some responsibility for Sunstein's skepticism. At times, they rely on overbroad claims about Article I, democracy, and the like. ${ }^{12}$ Although I ultimately believe that persuasive constitutional justifications support many aspects of statutory formalism, I must acknowledge that the current record leaves room for doubt. Consider, for example, the standard formalist arguments against using legislative history: Authoritative reliance on unenacted legislative history not only offends the requirements of bicameralism and presentment prescribed by Article I, Section $7,{ }^{13}$ but also violates Lockean nondelegation princi-

\footnotetext{
- See, for example, Cass R. Sunstein, Beyond the Republican Revival, 97 Yale I J 1539, 1558-66, 1581-85 (1988).

${ }^{10}$ See Cass R. Sunstein, Interpreting Statutes in the Regulatory State, 103 Harv I Rev 405, 498-99 (1989).

"See Sunstein, 66 U Chi L Rev at 662-63 (cited in note 1).

12 See id at 662-66.

${ }^{13}$ See, for example, Begier v IRS, 496 US 53, 68 (1990) (Scalia concurring) ("Congress conveys its directions through the Statutes at Large, not in excerpts from the Congressional Record."); Frank H. Easterbrook, Text, History, and Structure in Statutory Interpretation, 17 Harv J L \& Pub Pol 61, 68-69 (1994) ("No matter how well we can know the wishes and desires of legislators, the only way the legislature issues binding commands is
} 
ples implicit in the vesting clause of Article I, Section 1. ${ }^{14}$ Putting to one side Professor Sunstein's contention that the procedures for enacting a text do not tell us how to determine textual meaning, ${ }^{15}$ both of these constitutional arguments are in tension with other premises to which formalists subscribe. ${ }^{16}$ For example, modern formalists recognize that language is a social enterprise that yields meaning only in context. ${ }^{17}$ Hence, they routinely derive statutory meanings from extratextual sources, including unenacted materials such as cases or treatises that define terms of art or prescribe canons of construction. ${ }^{18}$ However justifiable it may be to consult these sources, they surely cannot claim the legitimation of bicameralism and presentment. Similar concerns apply to the nondelegation argument. Modern formalists acknowledge that all texts require exposition when applied to specific factual situations, ${ }^{19}$ and hence that agencies and courts inevitably enjoy some delegated authority to specify the details of

to embed them into law.").

" See US Const, Art I, $\$ 1$ ("All legislative Powers herein granted shall be vested in a Congress of the United States, which shall consist of a Senate and a House of Representatives."). See also Bank One Chicago, NA. v Midwest Bank \& Trust Co, 516 US 264, 280 (1996) (Scalia concurring in part and concurring in the judgment) ("It has always been assumed that these powers are nondelegable_or, as John Locke put it, that legislative power consists of the power "to make laws, ... not to make legislators."), quoting John Locke, Second Treatise of Government 87 (H. Davidson 1982) (R. Cox, ed).

${ }^{\text {ts }}$ See Sunstein, $66 \mathrm{U}$ Chi L Rev at 662-63 (cited in note 1). The constitutional process for lawmaking necessarily affects the choice of interpretive methodology, at least to some degree. At a minimum, the lawmaking process provides a rule of recognition for distinguishing between authoritative and unauthoritative texts. For example, if federal courts began to treat post-enactment reports of the House Ways and Means Committee as definitive expositions of the tax laws, such a practice would undermine any distinction between legislative texts that had or had not undergone the process of bicameralism and presentment.

${ }^{16}$ This discussion builds on analysis set forth in John F. Manning, Textualism as a Nondelegation Doctrine, 97 Colum L Rev 673, 699-705 (1997).

${ }_{17}$ See, for example, Easterbrook, 17 Harv J L \& Pub Pol at 64 (cited in note 13) ("Because interpretation is a social enterprise, because words have no natural meanings, and because their effect lies in context, we must consult these contexts.").

${ }^{18}$ See, for example, Babbitt $v$ Sweet Home Chapter of Communities for a Greater Oregon, 515 US 687, 717-18 (1995) (Scalia dissenting) (using pre-enactment cases and treatises to help define statutory term of art); Moskal $v$ United States, 498 US 103, 122-25 (1990) (Scalia dissenting) (same). Justice Scalia has also joined opinions of the Court applying substantive rules of construction, such as "the canon that provisions for benefits to members of the Armed Services are to be construed in the beneficiaries' favor." King $v$ St. Vincent's Hospital, 502 US 215, 220-21 n 9 (1991).

${ }^{19}$ See, for example, Mistretta $v$ United States, 488 US 361, 415 (1988) (Scalia dissenting) (conceding that "no statute can be entirely precise"); NBD Bank, N.A. v Bennett, 67 F3d 629, 633 (7th Cir 1995) (opinion by Easterbrook) ("No Member of Congress can anticipate all questions that will come to light; and a body containing hundreds of members with divergent agendas can't answer even a small portion of the questions that do occur to its members."). 
statutory meaning. ${ }^{20}$ But of course this casts doubt on any effort to deduce an exclusionary rule for legislative history from a straightforward application of Lockean principles.

In an effort to reconcile these apparent inconsistencies, I have argued elsewhere that the formalist approach to legislative history implements a more specific constitutional tradition against legislative self-delegation. ${ }^{21} \mathrm{I}$ leave it to the reader to assess that particular contention. For present purposes, the more important point is that some of the formalists' self-confidently deductive arguments on statutory interpretation have made it possible to denounce their constitutional conclusions as . . . well, excessively formalistic. That surely does not mean that we should abandon any effort to consult the Constitution on such matters. Indeed, to do so would be to indulge in an odd form of guilt by association: Some of the formalist constitutional arguments don't hold up, so we must abandon the Constitution altogether as a source of interpretive values. It simply does not follow. To state this objection, of course, is not to make the affirmative case for using constitutional structure to evaluate the competing methodologies. It is to that inquiry that I now turn.

\section{STATUTORY INTERPRETATION AS CONSTITUTIONAL LAW}

To understand the Constitution's relevance here, it is helpful to frame the inquiry in terms of some of Professor Sunstein's specific pleas for empirical study. For example, he contends that formalists might defend their approach through empirical studies calculated to show that formalism performs better than antifor-

${ }^{20}$ See, for example, Mistretta, 488 US at 415-17 (Scalia dissenting) (accepting weak version of nondelegation doctrine); Atchison, Topeka, and Santa Fe Railway Co v Pena, 44 F3d 437, 445 (7th Cir 1994) (Easterbrook concurring) ("When Congress has given an agency power to adopt legal norms via formal rule-making or administrative adjudication, the court must accept action within the scope of the delegated power the same way it accepts legislation.").

"I In brief, the Court has drawn a clear constitutional line that permits Congress wide latitude to delegate law-elaboration authority to the coordinate branches, but not its own agents or members. See Manning, 97 Colum $\mathrm{L}$ Rev at 710-25 (cited in note 16). In so doing, it has put Congress to the choice of "formulat[ing] the details" of statutory policy itself or assigning to the coordinate brances the responsibility for doing so. Metropolitan Washington Airports Authority $v$ Citizens for the Abatement of Aincraft Noise, Inc, 501 US 252, 272 (1991). The rationale for this distinction is straightforward: If Congress enacts a vague or ambiguous statute that leaves the details of meaning to a court or an executive agency, it cedes substantial control over policymaking to a constitutional rival. This reality imposes a structural check on the enactment of vague or open-ended legislation. If, however, prevailing rules of interpretation enable Congress to enact vague statutes while delegating policy details to its own agents (the committees and floor managers who create legislative history), that important structural incentive against delegation is compromised. 
malism as a market-mimicking or information-eliciting default rule. ${ }^{22}$ But why should we focus on those interpretive values? To some extent, because they have sometimes come from the pens of modern formalists themselves, ${ }^{23}$ they are fair game for those, like Sunstein, who wish to test formalist commitments empirically. But the assessment of formalism should not be confined to taking and testing even the leading formalists' claims at face value; it should also involve critical evaluation of the basis and origin of those claims. In that vein, this Section will tentatively conclude that defenders and critics of formalism must, or at least should, ultimately locate relevant interpretive values in the Constitution's structural commitments.

The basic starting point for analysis must be the Constitution. Because Congress has generally declined to prescribe rules to govern statutory interpretation, ${ }^{24}$ the task has necessarily fallen to the judiciary. If one accepts that the Constitution ultimately defines the scope and limits of all governmental authority at the federal level, then the legitimacy of the judiciary's development and application of interpretive rules must be justified by reference to the Constitution. ${ }^{25}$ To pursue any particular interpre-

\footnotetext{
${ }^{22}$ See Sunstein, $66 \mathrm{U}$ Chi L Rev at 653-56 (cited in note 1). Sunstein defines an information-eliciting default rule as one that gives Congress an incentive to enact more transparent legislation. See id at 655-56.

${ }^{25}$ See, for example, Finley $v$ United States, 490 US 545, 556 (1989) (opinion by Scalia) ("What is of paramount importance is that Congress be able to legislate against a background of clear interpretive rules, so that it may know the effect of the language it adopts."); United States v Taylor, 487 US 326, 345-46 (1988) (Scalia concurring in part) ("It should not be possible, or at least should not be easy, to be sure of obtaining a particular result in this Court without making that result apparent on the face of the bill which both Houses consider and vote upon, which the President approves, and which, if it becomes law, the people must obey."); Frank H. Easterbrook, Statutes' Domains, 50 U Chi L Rev 533, 541 (1983) ("If the purpose of the public interest statute is to come as close to the line of over-regulation as possible-that is, to achieve the benefits of regulation right up to the point where the costs of further benefits exceed the value of those benefits-then to authorize blank filling defeats the purpose of the statute.").

${ }^{24}$ Congress has prescribed only a few rules of interpretation, and none is terribly monumental. See, for example, 1 USC $\S 108$ (1994) ("Whenever an Act is repealed, which repealed a former Act, such former Act shall not thereby be revived, unless it shall be expressly so provided."); id $\S 109$ ("The repeal of any statute shall not have the effect to release or extinguish any penalty, forfeiture, or liability incurred under such statute, unless the repealing Act shall so expressly provide, and such statute shall be treated as still remaining in force for the purpose of sustaining any proper action or prosecution for the enforcement of such penalty, forfeiture, or liability."). Of course, even the proposition that Congress can legitimately prescribe rules of construction entails a conclusion of constitutional dimension. Note that in some countries, the legislatures have prescribed elaborate sets of rules for statutory interpretation. See, for example, The Acts Interpretation Act, No 11 NZ Stat 21 (1924) (New Zealand).

${ }^{25}$ See, for example, Jerry L. Mashaw, Textualism, Constitutionalism, and the Interpretation of Federal Statutes, $32 \mathrm{Wm} \&$ Mary L Rev 827, 839 (1991). This analysis presupposes an intelligible framework for interpreting the Constitution. Of course, to say that
} 
tive goal-mimicking the market, encouraging deliberation, limiting interest group influence, promoting equity, etc.-judges must be able to conclude either that the Constitution calls for (or at least inspires) the pursuit of those goals or that the federal courts themselves have inherent authority to adopt and apply such interpretive norms in the exercise of "the judicial Power." Either is a conclusion of constitutional dimension.

The point is not ternibly informative at that level of abstraction. But modern formalists have articulated a more specific account of the Constitution's influence on statutory interpretation. They contend that salient features of the constitutional structure-the separation of powers and checks and balances-deserve particular attention in the design of interpretive norms. ${ }^{27}$ While this Comment does not permit a detailed examination of that contention, I will sketch a possible justification for the formalist position. When a judge interprets a statute, the governing interpretive norms dictate the way that the judge deals with Congress and its commands. As Jane Schacter has put it, each act of interpretation is an "interbranch encounter of sorts."28 Selecting an interpretive methodology thus involves inevitable choices about the institutional allocation of power. ${ }^{29}$ If courts give strong deference

the structure of the Constitution alone supplies the norms of constitutional interpretation would be circular. At the outset of the Republic, questions about constitutional interpretation appeared to turn on assumptions about general interpretive practices. See, for example, H. Jefferson Powell, The Original Understanding of Original Intent, 98 Harv L Rev 885 (1985); Jack N. Rakove, Original Meanings: Politics and Ideas in the Making of the Constitution 342-64 (Knopf 1996). To acknowledge the need for an intelligible framework, however, does not presuppose an absence of debate about the proper method(s) of constitutional interpretation. See note 35 .

${ }^{28}$ US Const, Art III, §1. Mashaw makes a more decisive claim about the constitutional order:

To return, for example, to the notion of lending coherence to the law, one cannot rest with the simple assertion that coherence of the legal order is a good thing. One has to go on to say why coherence is important to a legal order-meaning a constitutional order-like ours. After all, in a despotic legal order, incoherence might be a good way for tyrants to keep their subjects off balance.

Mashaw, 32 Wm \& Mary L Rev at 839 (cited in note 25). Mashaw's point, however, ignores the possibility that "the judicial Power" may authorize judges to promote values that the Constitution does not directly mandate or inspire. The question whether the judicial power encompasses such authority is beyond the scope of this Comment.

${ }^{27}$ For examples of this emphasis, see text accompanying notes 13-14.

${ }^{2}$ Jane S. Schacter, Metademocracy: The Changing Structure of Legitimacy in Statutory Interpretation, 108 Harv L Rev 593, 593 (1995). See also id at 593-94 ("[S]tatutory interpretation represents the legal moment when a court confronts the product of the legislative branch and must assign meaning to a contested provision. To carry out its task, the court must adopt-at least implicitly - a theory about its own role by defining the goal and methodology of the interpretive enterprise and by taking an institutional stance in relation to the legislature.").

25 See Jerry Mashaw, As If Republican Interpretation, 97 Yale L J 1685, 1686-87 
to agencies' interpretations of the statutes they administer, that arrangement shifts law elaboration authority away from judges and toward the executive. ${ }^{30}$ If courts reject the authority of legislative history, they shift power away from committees and bill sponsors and toward agencies and courts. ${ }^{31}$ If courts start from an assumption of strong legislative supremacy in statutory cases, they define themselves as subordinates of the legislature. ${ }^{32}$

Our constitutional structure, of course, is hardly selfdefining. But much of it reflects the product of many important and often self-conscious debates and decisions about how best to allocate and check governmental power. ${ }^{33}$ Where the structure itself, its historical context, or the traditions surrounding it reveal a discernible purpose, it is at least useful, if not essential, to adopt rules of statutory interpretation that promote, rather than undermine, the objectives implicit in the institutional design. ${ }^{34}$

A concrete example follows shortly. But first it is necessary to acknowledge some obvious caveats. None of this is to suggest that inferences from constitutional structure will always provide

(1988):

Any theory of statutory interpretation is at base a theory about constitutional law. It must at the very least assume a set of legitimate institutional roles and legitimate institutional procedures that inform interpretation. Otherwise, rudimentary questions, such as whether a particular document presented for interpretation is a statute, or whether the presentation of that document in a particular context calls for an authoritative interpretation of it, cannot be answered. Beyond these very basic questions lie many more that determine ultimately what it means to speak authoritatively in a legislative or in a legal-interpretive voice. Such questions can be answered only by reference to the fundamental normative and institutional attributes of the state.

${ }^{30}$ See Cheuron USA, Inc v Natural Resources Defense Council, Inc, 467 US 837, 843-44 (1984) (holding that when a statute is "silent or ambiguous" on a particular question, "a court may not substitute its own construction of a statutory provision for a reasonable interpretation made by the administrator of an agency").

${ }^{31}$ See Manning, 97 Colum L Rev at 699-702 (cited in note 16).

${ }^{32}$ See, for example, Daniel A. Farber, Statutory Interpretation and Legislative Supremacy, 78 Georgetown I J 281, 284-87 (1989) (describing the strong conception of legislative supremacy).

* For a small sample of such deliberations, see, for example, Adrienne Koch, ed, Notes of Debates in the Federal Convention of 1787 Reported by James Madison 155-66 (Ohio 1966) (discussing bicameralism); id at 336-43 (debating and ultimately rejecting the association of judges with the President in the exercise of the veto); id at 460-65 (discussing the veto); Federalist 62 (Madison), in Clinton Rossiter, ed, The Federalist Papers 376, 378 (Mentor 1961) (checking power of bicameralism); Federalist 70 (Hamilton), in id at 423, 426-27 (deliberative values of bicameralism); Federalist 73 (Hamilton), in id at 441, 443 (salutary effects of the presidential veto); Federalist 78 (Hamilton), in id at 464, 469 (powers of judiciary).

* For a fuller version of this argument, see John F. Manning, Constitutional Structure and Judicial Deference to Agency Interpretations of Agency Rules, 96 Colum L Rev 612, 636-37 (1996). 
clear answers to questions of interpretive design. When they do not, the judiciary may have room to make choices among particular interpretive strategies. Nor is it remotely likely that constitutional analysts will always agree on the precise content of the applicable structural norms. ${ }^{35}$ For those scholars who believe that Cheuron serves representative democracy by shifting interpretive policymaking authority away from less accountable judges and toward more accountable agencies, there will surely be others who claim that strong judicial deference offends Marbury's premise that it is "emphatically the province and duty of the judicial department to say what the law is. ${ }^{p 36}$ But such differences of opinion are endemic to constitutional discourse, and we do not allow them to deter us from enforcing other constitutional values. It is not apparent then why the possibility of disagreement and debate over values should have a particular disabling effect in the context of interpretive design.

A final point bears mentioning. One might argue that drawing inferences from constitutional structure is itself a decidedly antiformalist interpretive strategy. Because no constitutional provision expressly speaks to statutory interpretation, deriving norms of statutory construction from structural constitutional policies might appear to be nothing short of high purposivism. Thus, does one have to be a constitutional antiformalist in order to be a statutory formalist? The answer is probably no. Formalist judges routinely use purpose to resolve ambiguity ${ }^{37}$ and sometimes derive such purpose from the structure of a legal scheme. ${ }^{38}$ If, in the absence of explicit direction, judges must inevitably fill in the blanks of statutory construction, it does little violence to formalism to suggest that they design the resulting norms to fit sensibly within the web of structural relationships that the Constitution prescribes.

\footnotetext{
${ }^{35}$ Indeed, there will be important antecedent disagreements about the appropriate way to interpret the Constitution. Are we originalists or nonoriginalists? That having been decided, to which of the many variants of originalism or nonoriginalism do we subscribe? What is the role of stare decisis in all of this? Do we proceed from the structural assumptions of the New Deal or the Philadelphia Convention? Are both relevant? The list could go on indefinitely.

${ }^{36}$ Marbury $v$ Madison, 5 US (1 Cranch) 49, 70 (1803).

"See, for example, Easterbrook, 17 Harv J I \& Pub Pol at 64 (cited in note 13) ("The goals, purposes, and concerns of the authors illuminate things."); Antonin Scalia, Judicial Deference to Administrative Interpretations of Law, 1989 Duke L J 511, 515 ("[I]t seems to me that the 'traditional tools of statutory construction' include not merely text and legislative history but also, quite specifically, the consideration of policy consequences.").

${ }^{3}$ See United States v Fausto, 484 US 439, 443-44, 449 (1988) (opinion by Scalia) (deriving purpose of Civil Service Reform Act from its statutory structure).
} 


\section{AN EXAMPLE OF LINGERING QUESTIONS: FAITHFUL AGENT VERSUS COMMON LAW THEORIES OF JUDGING}

Concluding that constitutional structure supplies the relevant interpretive values does not itself undermine Professor Sunstein's conclusion that the time has come to argue about facts, rather than values. If formalists and antiformalists agree on a clear framework of relevant values, or if useful debate has been exhausted, a shift to empirical inquiry seems justified. This Section will use a concrete example-Sunstein's proposed marketmimicking default rule-to suggest that we have not yet reached that point.

Professor Sunstein contends that empirical inquiry will help to verify whether formalism or antiformalism provides a superior market-mimicking default rule-that is, a rule that captures what the legislature would have done if it had explicitly confronted the precise question in issue. But even assuming that one could construct a reliable empirical inquiry, ${ }^{39}$ one must first ask whether the Constitution calls upon judges to mimic the legislative market. Most scholars and judges, both formalists and antiformalists, agree that it does. ${ }^{40}$ Such a conclusion, of course, reflects the widely shared premise that judges must act as "faithful agents" of the legislature. ${ }^{41}$ Indeed, the rival methodological camps often divide over the relatively narrow question of how best to be a faithful agent. Consider, for example, the clash over the inevitable problem of texts that are overinclusive or underinclusive relative to their ultimate purposes. ${ }^{42}$ Antiformalists be-

\footnotetext{
${ }^{39}$ Some formalists argue that legislative realities such as logrolling, strategic voting, and agenda control make it difficult, if not impossible, to reconstruct the way a legislature would have resolved an issue that it did not explicitly address. See, for example, Easterbrook, $50 \mathrm{U}$ Chi L Rev at 547-48 (cited in note 23).

${ }^{40}$ Compare, for example, Easterbrook, 98 Harv L Rev at 60 (cited in note 4) ("Judges must be honest agents of the political branches. They carry out decisions they do not make."), with West Virginia University Hospitals, Inc v Casey, 499 US 83, 115 (1991) (Stevens dissenting) ("In the domain of statutory interpretation, Congress is the master.").

${ }^{41}$ For descriptions of that assumption, see, for example, Sunstein, 103 Harv L Rev at 415 (cited in note 10) ("According to the most prominent conception of the role of courts in statutory construction, judges are agents or servants of the legislature. . . The judicial task is to discern and apply a judgment made by others, most notably the legislature."); Nicholas S. Zeppos, Chief Justice Rehnquist, the Two Faces of Ultra-Pluralism, and the Originalist Fallacy, 25 Rutgers L J 679, 685 (1994) ("Under traditional learning, the roles of Congress and the Court in interpreting statutes are neatly divided. The Court interprets a statute as a faithful agent of Congress.").

${ }^{42}$ Sometimes texts are precise and clear when considered in their linguistic and cultural environments. See Felix Frankfurter, Some Reflections on the Reading of Statutes, 47 Colum L Rev 527, 534 (1947) ("Even in matters legal some words and phrases, though very few, approach mathematical symbols and mean substantially the same to all who have occasion to use them."); Richard A. Posner, Legal Formalism, Legal Realism, and the
} 
lieve that when a clear text produces a result plainly at variance with the overall policy of the legislation, judges should adapt the specific text to its ultimate purpose. ${ }^{43} \mathrm{~A}$ common rationale for this view incorporates market-mimicking assumptions. If judges properly serve as Congress's "faithful agent," no such agent should insist upon compliance with the specific commands of a principal who is often imprecise or short-sighted in reducing its purposes to words. ${ }^{44}$ Textualists reply that enforcing actual statutory outcomes, rather than apparent purposes, produces a superior market-mimicking effect. They emphasize that a statute's details may emerge from bargains struck among the diverse interest groups who often comprise the enacting coalition; hence, the specifics of a statutory text may reflect a compromise, rather than an entirely coherent expression of legislative purpose. ${ }^{45}$

Notice that both methodological camps appear to start from the same assumption as Professor Sunstein-that federal judges should merely mimic the legislative market by attempting to implement congressional commands, however conceived. But that apparent consensus is misleading. For the faithful agent theory,

Interpretation of Statutes and the Constitution, 37 Case W Res I Rev 179, 187 (1986) ("A text is clear if all or most persons, having the linguistic and cultural competence assumed by the authors of the text, would agree on its meaning."). No matter how clear the text may be, its specific commands will never correspond precisely to its vitimate purposes. See Max Radin, Statutory Interpretation, 43 Harv I Rev 863, 874-77 (1930) (discussing "immediate" and "ultimate" purposes). The more precise a text, the more likely it is to be overinclusive and underinclusive. See, for example, Colin S. Diver, The Optimal Precision of Administrative Rules, 93 Yale L J 65, 73 (1983); Louis Kaplow, Rules Versus Standards: An Economic Analysis, 42 Duke I J 557, 591 (1992). This problem of course grows with the passage of time. See William N. Eskridge, Jr., Spinning Legislative Supremacy, 78 Georgetown L J 319, 324 (1989) ("[A]s time passes, problems arise about which the legislature gave little or no thought.").

is See, for example, United States v American Trucking Associations, Inc, 310 US 534, 543 (1940) ("[E]ven when the plain meaning [does] not produce absurd results but merely an unreasonable one 'plainly at variance with the policy of the legislation as a whole' th[e] Court [should] follow[ ] that purpose, rather than the literal words.") (citations omitted).

4 For expressions of this position, see, for example, Casey, 499 US at 115 (Stevens dissenting) ("W]e do the country a disservice when we needlessly ignore persuasive evidence of Congress' actual purpose and require it 'to take the time to revisit the matter' and to restate its purpose in more precise English whenever its work product suffers from an omission or inadvertent error.") (footnote omitted); Lon L. Fuller, The Case of the Speluncean Explorers, 62 Harv L Rev 616, 625-26 (1949) (opinion of Foster) ("No superior wants a servant who lacks the capacity to read between the lines. . . The correction of obvious legislative errors or oversights is not to supplant the legislative will, but to make that will effective.").

"s See Hrubec $v$ National Railroad Passenger Corp, 49 F3d 1269, 1270 (7th Cir 1995) (opinion by Easterbrook) ("Many laws are compromises, going thus far and no further in pursuit of a goal."); Contract Courier Services, Inc v Research \& Special Programs Administration, 924 F2d 112, 115 (7th Cir 1991) (opinion by Easterbrook) ("Statutes do more than point in a direction. ... They achieve a particular amount of [an] objective, at a particular cost in other interests."). 
at least in its strong form, has come under substantial and serious challenge. My colleague Peter Strauss, for example, has recently argued that "the American legal system is, as a matter of constitutional commitment, a common law system, in which law emerges from the decisions of judges as well as the votes of legislatures." ${ }^{\text {"46 }}$ The Constitution, in other words, does not confine judges merely to the subordinate role of implementing legislative commands. Strauss's common law conception of interpretation is hardly unprecedented. ${ }^{47}$ Indeed, proponents of this view of judging claim an originalist pedigree. William Eskridge, for example, has argued that English judges traditionally enforced "the equity of the statute," rather than the precise details of a statutory text; that founding era debates reflected the influence of this preconstitutional tradition; and that early American courts, in fact, exercised that authority. ${ }^{48}$

Regardless of whether such challenges to the faithful agent theory ultimately prove persuasive,${ }^{49}$ the important point is that

\footnotetext{
${ }^{48}$ Peter L. Strauss, The Common Law and Statutes, 70 U Colo L Rev 225, 235 (1999). Strauss also emphasizes, however, that in implementing their common law interpretive authority, judges should be willing "to learn from and respect the political history of legislation." Peter L. Strauss, The Courts and the Congress: Should Judges Disdain Political History?, 98 Colum L Rev 242, 243 (1998).

${ }^{47}$ Earlier this century, for example, Harlan Fiske Stone called upon judges to abandon the "illusion that in interpreting [statutes] our only task is to discover the legislative will," urging them instead to view a new statute "as an exemplification of a general principle which is to take its place beside other precepts, whether found in codes or accepted expositions of the jurists, as an integral part of the system, there to be extended to analogous situations not within its precise terms." Harlan Fiske Stone, The Common Law in the United States, 50 Harv L Rev 4, 13, 15 (1936). See also, for example, James M. Landis, Statutes and the Sources of Law, in Harvard Legal Essays 213, 233 (Harvard 1934) (exhorting judges to "interpret expressions of policy in light of the manifold circumstances responsible for the statutory formulations" and to give statutes a "functional construction"); Max Radin, A Short Way with Statutes, 56 Harv L Rev 388, 396-99, 406-08 (1942) (questioning the faithful agent theory, in part on the ground that "our legislature is not more and not less sovereign than administrators or judges").

${ }^{48}$ William N. Eskridge, Jr., Dynamic Statutory Interpretation, 135 U Pa L Rev 1479, 1501-03 (1987). See also William N. Eskridge, Jr., Textualism, The Unknown Ideal?, 96 Mich L Rev 1509, 1523-26 (1998) (describing eighteenth century theory and practice of statutory interpretation).

4 The originalist claims of the proponents of equitable interpretation are surely open to question. For example, some scholars have suggested that the ancient English practice of equitable interpretation was a remnant of conditions having little or no relevance to American constitutional circumstances. See, for example, Frederick J. deSloovère, The Equity and Reason of a Statute, 21 Cornell L Q 591, 591-93 (1936) (arguing that equitable interpretation originally may have arisen because of the imprecision of early English statutes, the indistinct provinces of English legislators and judges, the role of early English judges in drafting as well as interpreting legislation, the influences of natural law theories of judging, and struggles between the Parliament and Crown). With respect to early American practice, John Choon Yoo has persuasively argued that as early as John Marshall's tenure as Chief Justice, the Court's interpretive practice had already moved to an
} 
the very relevance of a market-mimicking default rule inescapably depends upon a constitutional premise-the faithful agent theory-that must be justified, if at all, through constitutional, not empirical, inquiry.

\section{CONCLUSION}

Professor Sunstein has asked whether formalism must be defended empirically. Perhaps empirical inquiry would cast light on important questions. If, for example, statutes became more precise once the Court reduced its reliance on legislative history after 1986, we would know something valuable about whether textualism in fact serves the interests of the nondelegation doctrine. That conclusion and others, however, must not obscure the fact that any values we test must be traced ultimately to constitutional premises. Certainly empirical tests cannot give us our values; they presuppose that we value certain things and not others in the lawmaking process and what they do is help us ascertain how well those (independently established) values are served by particular interpretive practices. In the absence of legislative prescription, the fundamental norms of interpretation are judgemade rules that necessarily affect the allocation of power among the branches of government. In our system of government, the Constitution determines that allocation. It will do so with varying degrees of clarity on various questions, to be sure. And constitutional arguments will be more or less persuasive. That is an occupational hazard of those who practice constitutional law. It does not negate the fact that any evaluation of statutory formalism and antiformalism must begin with the Constitution.

emphasis on implementing the will of Congress. See John Choon Yoo, Note, Marshall's Plan: The Early Supreme Court and Statutory Interpretation, 101 Yale L J 1607, 1616-30 (1992). An analysis of the original understanding of "the judicial Power" in relation to statutory interpretation is a question for another day. See John F. Manning, Textualism, Purposivism, and Legislative Supremacy (unpublished manuscript on file with author) (taking a skeptical view of the practice of equitable interpretation). 